\title{
Nutrient and phytoplankton biomass in the Amazon River shelf waters
}

\author{
MARIA L.S. SANTOS ${ }^{1}$, KÁTIA MUNIZ ${ }^{2}$, BENÍCIO BARROS-NETO ${ }^{3}$ \\ and MOACYR ARAUJO ${ }^{2}$ \\ ${ }^{1}$ Faculdade de Engenharia de Pesca, Campus Universitário de Bragança, Universidade Federal do Pará (UFPA) \\ Alameda Leandro Ribeiro s/n, 68600-000 Bragança, PA, Brasil \\ ${ }^{2}$ Departamento de Oceanografia, Universidade Federal de Pernambuco (UFPE) \\ Av. Arquitetura s/n, 50740-550 Recife, PE, Brasil \\ ${ }^{3}$ Departamento de Química Fundamental, Universidade Federal de Pernambuco (UFPE) \\ Av. Arquitetura s/n, 50740-550 Recife, PE, Brasil \\ Manuscript received on July 29, 2007; accepted for publication on May 23, 2008; \\ presented by ALCIDES SIAL
}

\begin{abstract}
The Amazon River estuary is notable at the Amazon Continental Shelf, where the presence of the large amount of water originating from the Amazon during the river's falling discharge period was made evident by the low salinity values and high nutrient levels. Even so, the presence of oceanic waters in the shelf area was significant. Dissolved organic nitrogen was the predominant species of the nitrogen cycle phases, followed by total particulate nitrogen, nitrate, ammonium and nitrite. The chlorophyll $a$ data in the eutrophic area indicated that there is sufficient nitrogen in the area to withstand productivity, though dissolved inorganic nitrogen removal processes are faster than regeneration or mineralization. The anomalous amounts of inorganic dissolved nitrogen showed more removal than addition. The simulations with the bidimensional MAAC-2D model confirmed that high nutrient waters are displaced northwestward (two cores at $2.5^{\circ} \mathrm{N}-50^{\circ} \mathrm{W}$ and $4^{\circ} \mathrm{N}-51^{\circ} \mathrm{W}$ ) by the stronger $\mathrm{NBC}$ during falling river discharge. During high river flow period these nutrient-rich lenses are distributed around $0.5^{\circ} \mathrm{N}-48.5^{\circ} \mathrm{W}$ as well as along the shallow Amazonian shelf $\left(20 \mathrm{~m}-50 \mathrm{~m}\right.$ depth, $\left.1^{\circ} \mathrm{N}-3.5^{\circ} \mathrm{N}\right)$, as a result of the spreading of Amazon freshwater outflow.
\end{abstract}

Key words: Amazon Continental Shelf, nitrogen, phosphate, mathematical modeling.

\section{INTRODUCTION}

The equatorial Atlantic region has an important role over the thermohaline overturning cell and the global heat and freshwater budgets. The major ocean current reaching the Amazon mouth is the North Brazil Current (NBC), a northward flowing western boundary current that carries warm water across the equator, this seasonally retroflects into the North Equatorial Counter Current (NECC), which contributes to the formation of the anticyclone current rings (NBC rings). This region is also very complex by the generation and evolutions of the North Brazil Current (NBC) rings interactions be-

Correspondence to: Maria de Lourdes Souza Santos E-mail: mdelssantos@yahoo.com.br tween different zonal currents and water masses transformations. The NBC rings are a significant contributor to transporting water across current gyres and between hemispheres in the tropical Atlantic (Bourlès et al. 1999, Johns et al. 1998, Schott et al. 2003). In this context, the Amazon and Pará rivers are the main continental forcing to the adjacent coastal waters, giving rise to alterations in local and remote hydrological parameters. Only for example, the water discharge of the Amazon River into the continental shelf is between $100,000 \mathrm{~m}^{3} \mathrm{~s}^{-1}$ and $220,000 \mathrm{~m}^{3} \mathrm{~s}^{-1}$, and the solid discharge is of 11 to $13 \times 10^{8}$ tons year $^{-1}$ (Kineke et al. 1996).

Field data used in this paper was collected during the R/V Antares cruises in Northern Brazil (1995-2001) 
as part of the REVIZEE (Programa Nacional de Avaliação do Potencial Sustentável de Recursos Vivos da Zona Econômica Exclusiva). The REVIZEE is a Brazilian Program for Assessing the Sustainable Potential of the Live Resources of the Exclusive Economic Zone (ZEE), within the ambit of the Inter-ministerial Commission for Sea Resources-CIRM that resulted from the commitment undertaken by Brazil in 1988, when ratifying the UN Convention on the Law of the Sea, in force since November 1994. Two specific oceanographic campaigns used herein - Operation Norte III (1999) and Operation Norte IV (2001) - were performed during the periods of high and falling discharge of the Amazon River, respectively.

Based on the physical and chemical data of the North III Operation, Santos (M.L.S. Santos, unpublished data) characterized the Amazon Continental Shelf as a eutrophic environment, particularly because of the chlorophyll $a$ values, which had a median of $1.64 \mathrm{mg} \mathrm{m}^{-3}$. As described by Humborg (1997), increase in the primary productivity in this shelf occurs where nutrient concentrations and the penetration of light are favorable to phytoplankton growth.

According to DeMaster and Pope (1996), the external source of nutrients responsible for algal blooms on the outer shelf depends on which nutrients predominate. Nearly all of the silicate $(83 \%)$ and most of the nitrate $(62 \%)$ supplied to the outer shelf come from the river itself, whereas only half of the phosphate and only a fifth of the ammonium have a river source. The shoreward advection of subsurface waters is the dominant ammonium source and an important source of phosphate to the algal blooms on the outer shelf. This flow carries 5-10 times the annual flow from the Amazon River.

The overall goal of this research was to examine the processes controlling nutrient uptake and primary production on the Amazon shelf. To reach this goal, three specific objectives were pursued:

- A study of the distribution of abiotic parameters during the Amazon River's falling discharge period;

- Determining the concentration of nitrogen compounds in the same period;

- Simulation with the mathematical model to represent the horizontal distribution of phosphate and nitrate in the Amazon Continental Shelf, during the high and falling discharge periods.

\section{STUdy Site}

The Amazon shelf, which lies between the Pará estuary and approximately $5^{\circ} \mathrm{N}$ and between the coast and $100 \mathrm{~m}$ isobaths, has a broad gently dipping inner shelf (approximately $250 \mathrm{~km}$ in width), a steeper middle shelf (40-60 m depth), and an outer shelf extending to the shelf break at the $100 \mathrm{~m}$ isobaths (Nittrouer and DeMaster 1996).

Circulation on the Amazon shelf is a result of the complex interaction of river discharge, strong tidal currents, wind stress and the flow, close to the shore, of the North Brazilian Current (Nittrouer et al. 1991). Mixing of river and ocean waters occurs out on the Amazon shelf.

The magnitude and nature of the North Brazilian Current changes seasonally. The highest flow (30 Sverdrup) occurs in August (low river discharge); the lowest flow (10 Sv) takes place in April, during the high discharge period (Philander and Pacanowski 1986). From January to June, the North Brazilian Current moves northward along the coast of South America. Between June and December, however, the current retroflects eastward at about $5^{\circ} \mathrm{N}$ (Muller-Karger et al. 1988).

Depending on the location on the shelf, as well as on the tidal regime (high/low, spring/neap), the river/ ocean mixing zone can be characterized by isohaline distributions consistent with the classic "salt wedge" model or the "partially well-mixed" model of estuarine circulation (Geyer et al. 1996). Dissipation of tidal energy is a very important process, affecting salinity distributions on the shelf (Beardsley et al. 1995), as well as sediment transport (Kineke et al. 1996).

Winds on the shelf are predominantly easterly trade winds, which are most intense between January and March and weakest in August and September (Picaut et al. 1985, Lentz 1995a). Lentz (1995b) concluded that even weak along-shelf wind stresses induce very strong surface currents, because the Amazon plume in this region is thin. Even in the absence of the southeast wind, the plume still flows out northwestward, indicating that wind is not the main force driving the Amazon waters towards the French Guyana Shelf. Apart from 
the along-shore current component leading the plume northwestward, Lentz also showed that the ambient flow was highly influenced by the semi-diurnal tidal component variation.

\section{MATERIALS AND METHODS}

\section{AnALytical Methods}

Water samples were collected in 5 L Niskin bottles, distributed in a Rosette connected to a CTD (Conductivity, Temperature, Depth), in 41 oceanographic stations located in the Amazon Continental Shelf (Fig. 1), during the North IV Operation (August 2001).

The following physical and chemical parameters were determined on board the ship: temperature and salinity (recorded from the data obtained with the CTD); dissolved oxygen (DO), determined by Winkler's method, described in Strickland and Parsons (1972); saturation rate of dissolved oxygen, obtained using UNESCO's International Oceanographic Tables (1973); $\mathrm{pH}$, measured with a HANNA pHmeter; and water transparency (determined with a Secchi disk), which allowed separation of the water column in the euphotic and aphotic layers.

To determine phosphate, ammonium, nitrate, nitrite and organic dissolved nitrogen, the water samples were filtered in $0.45 \mu \mathrm{m} \mathrm{GF} / \mathrm{F}$ Whatman filters, stored in 500$\mathrm{mL}$ polyethylene flasks and frozen. To determine total nitrogen, the water samples were stored in $250-\mathrm{mL}$ polyethylene flasks, without filtering.

Subsequently, the frozen water samples were thawed at the Oceanography Laboratory of the Pará Federal University, and analyzed in duplicate to determine the concentrations of the nutrients mentioned above, according to the methodology described in Grasshoff et al. (1983). The water required for the analyses was taken from an ALPHA Q. The precision of nutrient measurements was $2-5 \%$.

The total particulate nitrogen concentration (TPN) was obtained from analyses of the total nitrogen (in the unfiltered sample) and total dissolved nitrogen (in the filtered sample) by the oxidation method using potassium persulfate in a basic medium. The difference between the median values of total nitrogen and dissolved total nitrogen gives an estimate of the total particulate nitrogen.
The dissolved organic nitrogen concentration (DON) was estimated from the medians of the analyses made on the filtered samples, as the difference between dissolved total nitrogen and inorganic dissolved nitrogen (sum of nitrate, ammonium and nitrite).

The particulate organic and inorganic materials (POM and PIM) were determined by the gravimetric method described in Paranhos (1996). For chlorophyll $a$, the analyses were performed at the Laboratório de Produtividade Primária of the Oceanography Department of the Federal University of Pernambuco, using the method described in Teixeira (1973).

\section{Mathematical Model}

The bidimensional (2D) analytical model used in this study was the MAAC-2D model, developed in the Laboratory of Physical, Estuarine and Coastal Oceanography (LOFEC) of the Oceanography Department, Federal University of Pernambuco (DOCEAN/UFPE).

The MAAC-2D is a deterministic mathematical model with an analytically and temporally permanent solution. Its conception is based on the equation of the advective-diffuse transport of dynamically passive and biogeochemically active constituents. The equation (1) brings the balance of mass for each constituent $\mathrm{C}$ (also called state variable) in the MAAC-2D.

$$
\begin{gathered}
\underbrace{\frac{\partial \mathrm{C}}{\partial \mathrm{t}}}_{\begin{array}{c}
\text { temporal } \\
\text { variation }
\end{array}}+\underbrace{\mathrm{K} \frac{\partial^{2} \mathrm{C}}{\partial \mathrm{y}^{2}}}_{\begin{array}{c}
\text { advection } \\
\mathrm{v} \frac{\partial \mathrm{C}}{\partial \mathrm{y}}
\end{array}} \\
-\underbrace{\psi \mathrm{C}}_{\begin{array}{c}
\text { diffusion } \\
\text { biogeochemical } \\
\text { changes }
\end{array}}+\underbrace{\mathrm{J}(\mathrm{x}, \mathrm{y})}_{\begin{array}{c}
\text { external } \\
\text { sources }
\end{array}}
\end{gathered}
$$

where:

$$
\begin{aligned}
\mathrm{C}= & \text { concentration of the constituent } \\
& \mathrm{C}\left(\mu \mathrm{mol} \mathrm{L} \mathrm{L}^{-1}\right) \\
\mathrm{v}= & \text { ocean current speed in the direction } \\
& \text { OY }\left(\mathrm{m} \mathrm{s}^{-1}\right) \\
\mathrm{K}= & \text { horizontal dispersion coefficient }\left(\mathrm{m}^{2} \mathrm{~s}^{-1}\right) \\
\psi \quad & \text { rate of constituent change } \\
& - \text { biogeochemical mechanisms }\left(\mathrm{s}^{-1}\right) \\
\mathrm{J}(\mathrm{x}, \mathrm{y})= & \text { external input of constituent } \\
& \mathrm{C}\left(\mu \mathrm{mol} \mathrm{L} \mathrm{L}^{-1} \mathrm{~s}^{-1}\right) .
\end{aligned}
$$




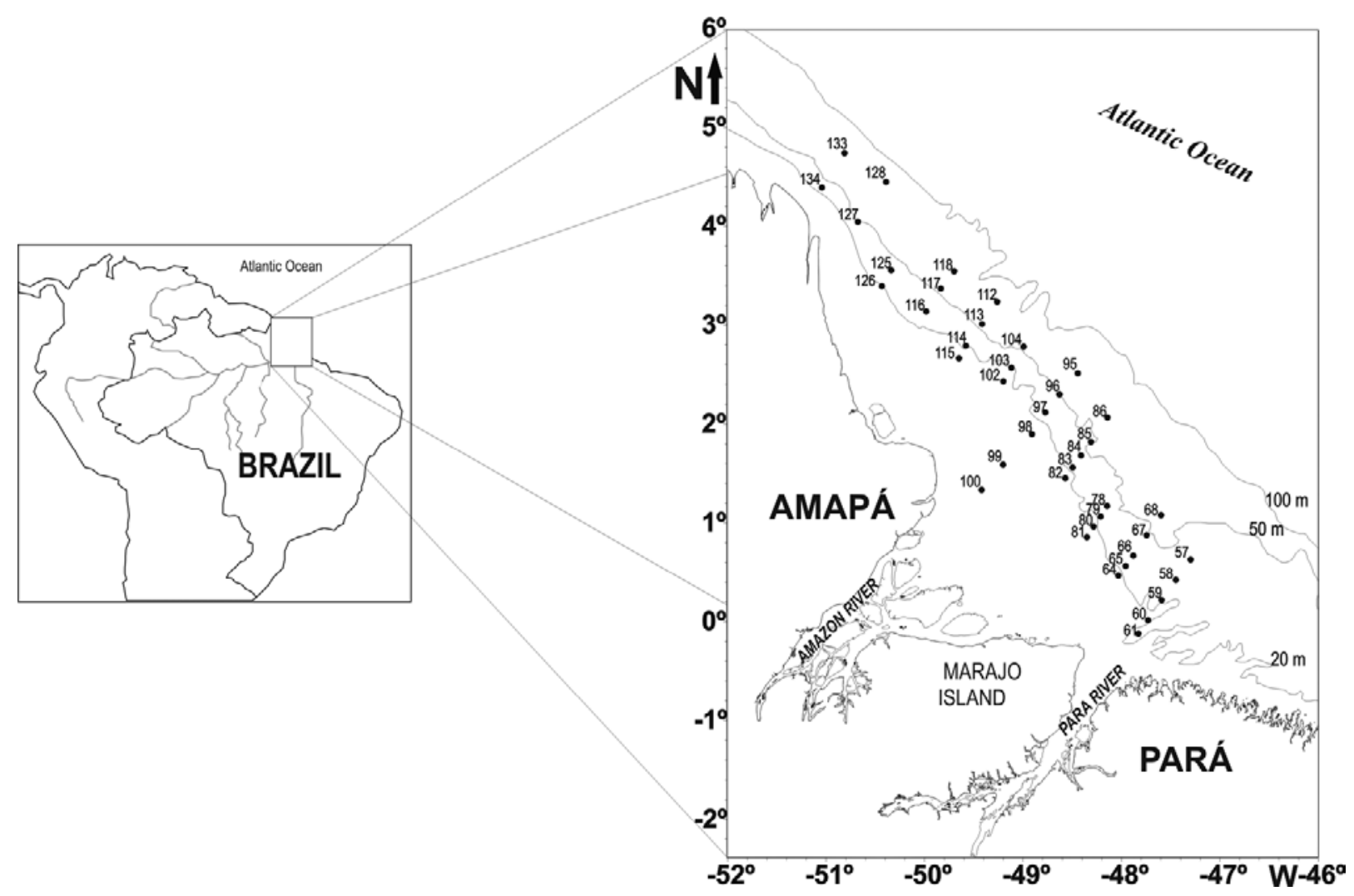

Fig. 1 - Map of the study area, showing the stations sampled during Operation North IV (Brazilian REVIZEE Program). becomes:

In the permanent situation $\left(\frac{\partial \mathrm{C}}{\partial \mathrm{t}} \cong 0\right)$, eq. (1)

$$
\begin{gathered}
\underbrace{\underbrace{\frac{\partial \mathrm{C}}{\partial \mathrm{y}}}_{\text {diffusion }}}_{\text {advection }}=\underbrace{\underbrace{\mathrm{KC} \frac{\partial^{2} \mathrm{C}}{\partial \mathrm{y}^{2}}}_{\begin{array}{c}
\text { external } \\
\text { sources }
\end{array}}}_{\begin{array}{c}
\text { biogeochemical } \\
\text { changes }
\end{array}} \\
-\underbrace{\mathrm{J}(\mathrm{x}, \mathrm{y})}_{\text {soung }}
\end{gathered}
$$

Eq. (2) allows a simple analytical solution when we consider initially $\mathrm{J}(\mathrm{x}, \mathrm{y})=0$, as follows:

$$
\mathrm{C}_{\mathrm{h}}=\mathrm{c}_{1} \mathrm{e}^{\mathrm{r}_{1} \mathrm{y}}+\mathrm{c}_{2} \mathrm{e}^{\mathrm{r}_{2} \mathrm{y}}
$$

where the values of $r_{1}$ and $r_{2}$ are the roots of the characteristic (second degree) equation given by,

$$
\mathrm{K} \mathrm{r}^{2}+\mathrm{vr}+\psi=0
$$

and whose coefficients are the values of parameters $\mathrm{K}$, $\mathrm{v}$ and $\psi$ of the proposed mathematical model - eq. (2).
The coefficients $c_{1}$ and $c_{2}$ in the eq. (3) are obtained from the resolution of a system of two first degree to two unknown equations, with the use of values of $\mathrm{C}$ in the limits $\mathrm{y}=0$ and $\mathrm{y}=\mathrm{y}_{\max }$ (boundary conditions given by the field data).

For $\mathrm{J}(\mathrm{x}, \mathrm{y}) \neq 0$ a source term appears as the solution of eq. (2). This term has the specific solution $\mathrm{C}_{\text {part. }}=\mathrm{J}(\mathrm{x}, \mathrm{y}) / \psi$, that should be added to the solution of the homogeneous equation. Therefore the complete solution of eq. (1) is obtained as a linear combination of both homogeneous and particular solutions:

$$
\mathrm{C}=\mathrm{C}_{\mathrm{h}}+\mathrm{C}_{\text {part }}
$$

The term $\mathrm{J}(\mathrm{x}, \mathrm{y})$ in eq. (2) confers the bidimensional character to the model. This term is related to the external bearing of constituent $\mathrm{C}$, representing mainly the continental contribution (river outflow and non-point loads, etc.) for the study area. The term $\mathrm{J}(\mathrm{x}, \mathrm{y})$ was adapted considering that the continental transport of nutrients falls offshore. Mathematically this mechanism has been 
taken into account through an exponential decay in the following way:

$$
\mathrm{J}(\mathrm{x}, \mathrm{y})=\mathrm{J}(0, \mathrm{y}) \exp (-\lambda \mathrm{x})
$$

where $(\mathrm{x}, \mathrm{y})$ is the transport at the coordinate $(\mathrm{x}, \mathrm{y})$ of the study area, $\mathrm{J}(0, \mathrm{y})$ is the continental contriburtion at the lower edge of the study area $(x=0)$, situated closer the coastline. $\lambda$ is the decay coefficient $\left(\mathrm{m}^{-1}\right)$ for the continental input, and $\mathrm{x}$ is the cross-shore distance along the OX axis (m).

It is important to stress that the use of the MAAC2D model is limited to bidimensional geophysical flows submitted to mean horizontal velocity fields. The model is not able to reproduce vertical transport and state variable distributions along the water depth. By the same time, MAAC-2D routines can only take into account water quality constituents driven by biogeochemical transformations that may be mathematically represented through first order kinetics. In this sense, toxic and heavy metals compounds cannot be simulated by MAAC-2D model.

Figure 2 shows the sampling stations of Operations Norte III (high discharge of the Amazon River) and Norte IV (period of falling discharge of the Amazon River), bounded by the integration domain used in the simulations with MAAC-2D model.

The boundary conditions in eq. (2) are given by the nutrient concentration values at the extremes $y=0$ and $\mathrm{y}=\mathrm{y}_{\max }$, by the along shore ocean current intensity $\mathrm{v}$, and by the term $\mathrm{J}(0, \mathrm{y})$ at eq. (6). These conditions were tested and chosen in order to represent numerically the situations observed during the river's high discharge period, as well as during the falling discharge period. The average current intensity v (of the North Brazil Current - NBC) used in simulations was estimated from the in situ measurements and calculus of Schott et al. (1998) and Johns et al. (1998). These authors covered the hydrography of the northern Brazilian coast in different transversal sections (i.e.: $35^{\circ} \mathrm{W}$ and $44^{\circ} \mathrm{W}$ ) using a LADCP (Lowered Acoustic Doppler Current Profiler).

The horizontal dispersion coefficient $\mathrm{K}$ and the kinematics rate $\psi$ in eq. (2) represent respectively the (turbulent + dispersion) flux and the balance between the mechanisms of removal and production of nutrients (nitrate/phosphate). The decay coefficient $\lambda$ in the eq. (3)

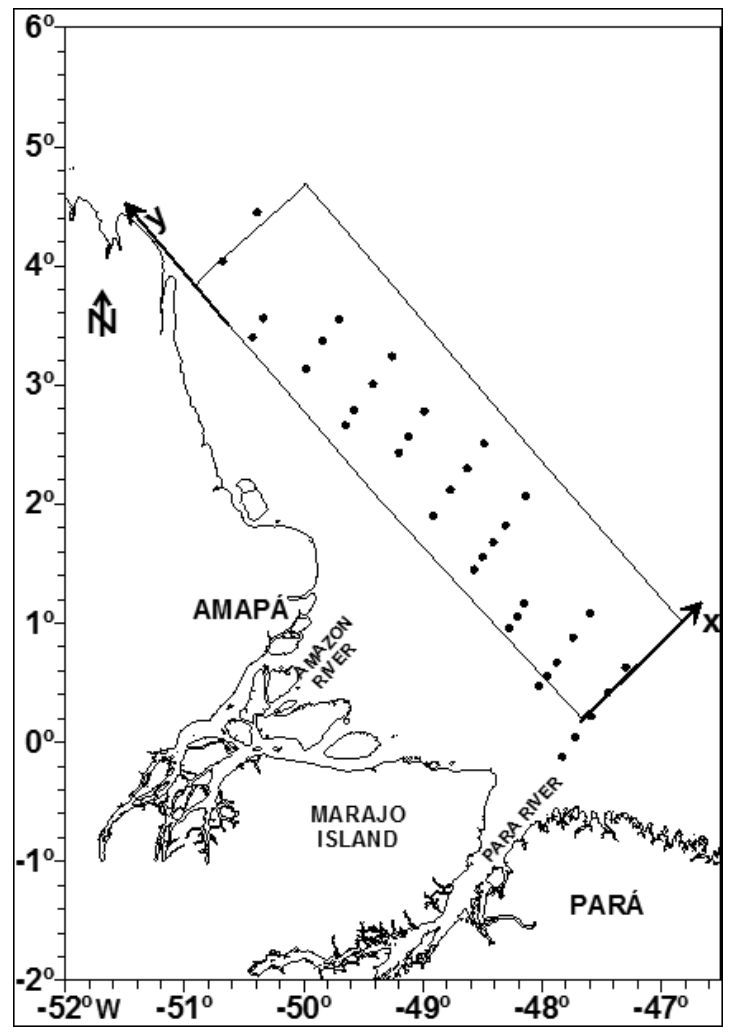

Fig. 2 - Map of the stations of the REVIZEE Program, and the integration domain used in the simulations with MAAC-2D.

is associated to the reduction of the continental contribution of nutrients along the OX axis. Table I shows the boundary conditions and the values of the rates and coefficients used in the simulations with the MAAC-2D model.

The values for $\mathrm{K}$ and $\psi$ were estimated from the theoretical/experimental results in addition to previous numerical works involving the study area (CLIPPER team 2000, Silva 2006, Silva et al. 2007). The crossshore decay $\lambda$ for $\mathrm{N}$ and $\mathrm{P}$, and those of $\mathrm{J}(0, \mathrm{y})$ were calibrated taking into account the best agreement between numerical results and experimental sea data. The best set of parameter values (see Table I) was obtained when the minimum value of the objective function

$$
\sigma=\sqrt{\frac{1}{N} \sum_{1}^{N} \frac{\left(x_{t}^{i}-x_{o}^{i}\right)}{x_{m}^{i}}}
$$

(computed after about 20 different performed simulations for each river discharge scenario) was achieved. In this formulation $n$ is the number of sample station, $x_{t}^{i}$ is the calculated value of the state variable (phosphate and 
TABLE I

Boundary condition values, rates and coefficients used in the simulations with the MAAC-2D model.

\begin{tabular}{l|c|c}
\hline & \multicolumn{2}{|c}{ Amazon river discharge - Periods } \\
\hline Boundary condition & High & Falling \\
\hline $\mathrm{V}\left(\mathrm{m} \mathrm{s}^{-1}\right)$ & 0.25 & 0.35 \\
\hline $\mathrm{J}(0, \mathrm{y})-$ Nitrate $\left(\mu \mathrm{mol} \mathrm{L}^{-1} \mathrm{~s}^{-1}\right)$ & $(9.954-10.001) \times 10^{-5}$ & $(9.958-10.001) \times 10^{-5}$ \\
\hline $\mathrm{J}(0, \mathrm{y})-$ Phosphate $\left(\mu \mathrm{mol} \mathrm{L}^{-1} \mathrm{~s}^{-1}\right)$ & $(9.948-10.000) \times 10^{-5}$ & $(9.946-10.000) \times 10^{-5}$ \\
\hline \hline Rates and Coefficients & & \\
\hline $\mathrm{K}\left(\mathrm{m}^{2} \mathrm{~s}^{-1}\right)$ & $6.0 \times 10^{4}$ & $6.0 \times 10^{4}$ \\
\hline$\psi\left(\mathrm{s}^{-1}\right)$ & $1.15 \times 10^{-8}$ & $1.15 \times 10^{-8}$ \\
\hline$\lambda\left(\mathrm{m}^{-1}\right)$ & $5.0 \times 10-3$ & $1.0 \times 10-2$ \\
\hline
\end{tabular}

nitrate), $\mathrm{x}_{\mathrm{o}}^{\mathrm{i}}$ is the corresponding measured value and $\mathrm{x}_{\mathrm{m}}^{\mathrm{i}}$ is the average, observed value of the state variable (phosphate and nitrate) (Jørgensen and Bendoricchio 2001).

\section{RESULTS}

\section{Period of Falling Discharge}

The descriptive statistics for the data recorded in the euphotic (13 $\mathrm{m}$ average depth) and aphotic (20 m average depth) layers are given in Tables II and III, respectively. The median values are higher for temperature, DO and dissolved oxygen saturation rate in the euphotic layer, whereas the aphotic layer has larger medians for nitrate, nitrite, phosphate, PIM and POM. Salinity, $\mathrm{pH}$ and ammonium medians are very similar in the two layers.

These differences indicate that photosynthesis in the euphotic layer favors an increase in dissolved oxygen, whereas, in the aphotic layer, the remineralization of organic material liberates nutrients in their inorganic form (nitrate and phosphate). The larger POM value for the aphotic layer indicates the liberation of organic material from several kinds of detritus, such as fecal balls and fragments of animal and plant tissue. The PIM increase may be associated to a resuspension of the deep sediments.

The box-and-whisker plot in Figure 3 allows a visual comparison of the temperature and salinity distributions in the euphotic and aphotic layers. In this kind of plot, the height of the box represents the interquartilic distance, the central point corresponds to median and the whiskers are limited by maximum and minimum values of the plotted variables. To compare in the same plot variables with different units, the data were first sub- jected to an autoscaling transformation, which consists in subtracting from the original values the mean of all recorded values for the variable under consideration and then dividing this difference by the standard deviation of the same data. Consequently, the values become dimensionless and can be easily compared. One of the features that stand out in Figure 3 is the large skewness of the salinity values, indicated by the long whiskers toward lower values. This is consistent with the location of sampling stations at the Amazon estuary. The temperature values are more spread out - and toward lower values - in the aphotic layer. This is also to be expected, as this layer corresponds to sampling points not affected by sunlight.

The boxplot of the autoscaled nutrient values is shown in Figure 4. They all have very skewed distributions, with long upper tails and smaller median values in the euphotic layer (nitrate $=2.12 \mu \mathrm{mol} \mathrm{L}^{-1}$, nitrite $=0.05 \mu \mathrm{mol} \mathrm{L}{ }^{-1}$, ammonium $=0.10 \mu \mathrm{mol} \mathrm{L}^{-1}$ and phosphate $=0.18 \mu \mathrm{mol} \mathrm{L}^{-1}$, as given in Table II). The interquartilic width for the nitrogenated forms indicates a variation in the distribution of the concentrations of these nutrients in both layers. In the euphotic layer, the nitrate and nitrite medians are closer to the minimum values, indicating a larger concentration of values close to the lower quartile. The interquartilic distances for phosphate are similar in both layers, with a larger median in the aphotic layer $\left(0.30 \mu \mathrm{mol} \mathrm{L}^{-1}\right.$, Table III).

In a marine environment, $\mathrm{pH}$ is controlled by the $\mathrm{CO}_{2}$ system, which maintains the acid-alkaline balance and favors marine life. Alkaline $\mathrm{pH}$ levels were observed in the entire water column, with the median val- 
TABLE II

Descriptive statistics of the abiotic and chlorophyll $a$ data recorded at the Amazon Continental Shelf in the euphotic layer, during the falling discharge period. Acronyms are as given in the text. $\mathrm{N}$ is the number of samples for which the statistical values were calculated.

\begin{tabular}{l|c|c|c|c|c|c}
\hline & $\mathrm{N}$ & Minimum & Maximum & Median & $\begin{array}{c}\text { First } \\
\text { Quartile }\end{array}$ & $\begin{array}{c}\text { Third } \\
\text { Quartile }\end{array}$ \\
\hline Temperature $\left({ }^{\circ} \mathrm{C}\right)$ & 79 & 25.55 & 28.96 & 28.08 & 27.39 & 28.53 \\
\hline Salinity & 79 & 0.00 & 36.42 & 36.01 & 33.70 & 36.30 \\
\hline DO $\left(\mathrm{mL} \mathrm{L}^{-1}\right)$ & 79 & 3.43 & 7.31 & 5.10 & 4.93 & 5.46 \\
\hline DO $(\%)$ & 79 & 73.68 & 153.75 & 112.03 & 108.82 & 121.7 \\
\hline pH & 78 & 7.38 & 8.14 & 7.74 & 7.71 & 7.99 \\
\hline Chlorophyll $a\left(\mathrm{mg} \mathrm{m}^{-3}\right)$ & 79 & 0.13 & 41.45 & 1.67 & 0.86 & 3.73 \\
\hline POM $\left(\mathrm{mg} \mathrm{L}^{-1}\right)$ & 62 & 4.80 & 94.30 & 34.10 & 29.80 & 47.20 \\
\hline PIM $\left(\mathrm{mg} \mathrm{L}^{-1}\right)$ & 62 & 1.00 & 106.40 & 23.10 & 13.00 & 30.00 \\
\hline TPM $\left(\mathrm{mg} \mathrm{L}^{-1}\right)$ & 62 & 29.20 & 158.00 & 58.2 & 55.00 & 60.80 \\
\hline Nitrate $\left(\mu \mathrm{mol} \mathrm{L}^{-1}\right)$ & 78 & 0.72 & 8.59 & 2.12 & 1.36 & 3.80 \\
\hline Nitrite $\left(\mu \mathrm{mol} \mathrm{L}^{-1}\right)$ & 78 & 0.01 & 0.59 & 0.05 & 0.03 & 0.13 \\
\hline Ammonium $\left(\mu \mathrm{molL}^{-1}\right)$ & 76 & 0.02 & 0.29 & 0.10 & 0.06 & 0.13 \\
\hline TPN $\left(\mu \mathrm{mol} \mathrm{L}^{-1}\right)$ & 78 & 12.14 & 92.92 & 34.03 & 39.98 & 28.00 \\
\hline DON $\left(\mu \mathrm{mol} \mathrm{L}^{-1}\right)$ & 76 & 38.79 & 167.91 & 85.28 & 94.96 & 78.90 \\
\hline TDN $\left(\mu \mathrm{mol} \mathrm{L}^{-1}\right)$ & 78 & 40.38 & 173.64 & 87.23 & 97.37 & 80.25 \\
\hline Phosphate $\left(\mu \mathrm{mol} \mathrm{L}^{-1}\right)$ & 78 & 0.06 & 0.77 & 0.18 & 0.12 & 0.30 \\
\hline
\end{tabular}

TABLE III

Descriptive statistics of the abiotic and chlorophyll $a$ data recorded at the

Amazon Continental Shelf in the aphotic layer, during the falling discharge period. Acronyms are as given in the text. $\mathrm{N}$ is the number of samples for which the statistical values were calculated.

\begin{tabular}{l|c|c|c|c|c|c}
\hline & $\mathrm{N}$ & Minimum & Maximum & Median & $\begin{array}{c}\text { First } \\
\text { Quartile }\end{array}$ & $\begin{array}{c}\text { Third } \\
\text { Quartile }\end{array}$ \\
\hline Temperature $\left({ }^{\circ} \mathrm{C}\right)$ & 53 & 23.72 & 28.95 & 27.51 & 26.17 & 28.49 \\
\hline Salinity & 53 & 0.00 & 36.42 & 36.18 & 35.01 & 36.29 \\
\hline DO $\left(\mathrm{mL} \mathrm{L}^{-1}\right)$ & 52 & 3.58 & 5.84 & 4.85 & 4.65 & 5.03 \\
\hline DO $(\%)$ & 52 & 80.71 & 122.37 & 104.92 & 100.88 & 109.82 \\
\hline pH & 52 & 7.32 & 8.12 & 7.72 & 7.69 & 7.76 \\
\hline POM $\left(\mathrm{mg} \mathrm{L}^{-1}\right)$ & 49 & 1.20 & 81.34 & 46.80 & 35.00 & 53.55 \\
\hline PIM $\left(\mathrm{mg} \mathrm{L}^{-1}\right)$ & 49 & 0.40 & 114.67 & 26.60 & 12.30 & 46.80 \\
\hline TPM $\left(\mathrm{mg} \mathrm{L}^{-1}\right)$ & 49 & 47.60 & 188.00 & 61.20 & 56.55 & 90.35 \\
\hline Nitrate $\left(\mu \mathrm{mol} \mathrm{L}^{-1}\right)$ & 50 & 1.60 & 13.48 & 3.32 & 2.67 & 4.65 \\
\hline Nitrite $\left(\mu \mathrm{mol} \mathrm{L}^{-1}\right)$ & 50 & 0.01 & 0.88 & 0.18 & 0.05 & 0.41 \\
\hline Ammonium $(\mu \mathrm{mol} \mathrm{L}-1)$ & 50 & 0.02 & 0.31 & 0.12 & 0.10 & 0.17 \\
\hline TPN $\left(\mu \mathrm{mol} \mathrm{L}^{-1}\right)$ & 50 & 19.41 & 97.10 & 34.27 & 43.43 & 29.71 \\
\hline DON $\left(\mu \mathrm{mol} \mathrm{L}^{-1}\right)$ & 50 & 30.62 & 125.30 & 81.98 & 89.10 & 71.18 \\
\hline TDN $\left(\mu \mathrm{mol} \mathrm{L}^{-1}\right)$ & 50 & 37.08 & 128.02 & 84.95 & 94.26 & 77.66 \\
\hline Phosphate $\left(\mu \mathrm{mol} \mathrm{L}^{-1}\right)$ & 50 & 0.12 & 0.89 & 0.30 & 0.20 & 0.39 \\
\hline
\end{tabular}


ues very similar for the two layers (7.74 and 7.72 for the euphotic and aphotic layers, respectively).

For DO distribution and its saturation rate, the medians were $5.10 \mathrm{~mL} \mathrm{~L}^{-1}(112.03 \%)$ in the euphotic layer and $4.84 \mathrm{~mL} \mathrm{~L}^{-1}(104.90 \%)$ in the aphotic layer. These values are characteristics of a saturated to supersatured environment.

As shown in Tables II and III, the phases of the nitrogen cycle in the water column are in order of decreasing values DON, followed by NTP, nitrate, ammonium and nitrite, for both layers. The predominant nitrogen form in the entire water column is therefore dissolved organic nitrogen (euphotic layer: $38.79 \mu \mathrm{mol} \mathrm{L}^{-1}$ minimum, $167.91 \mu \mathrm{mol} \mathrm{L}^{-1}$ maximum, $85.28 \mu \mathrm{mol} \mathrm{L}^{-1}$ median; aphotic layer: $30.62 \mu \mathrm{mol} \mathrm{L}^{-1}$ minimum, $125.3 \mu \mathrm{mol} \mathrm{L}^{-1}$ maximum, $81.98 \mu \mathrm{mol} \mathrm{L}^{-1}$ median). The maximum overall value, $167.91 \mu \mathrm{mol} \mathrm{L}^{-1}$ was determined at Station 134, where the largest phytoplankton biomass concentration was also measured (41.45 $\left.\mathrm{mg} \mathrm{m}^{-3}\right)$.

The concentration of total particulate material (TPM) during the period of falling discharge of the Amazon River varied from $29.20 \mathrm{mg} \mathrm{L}^{-1}$ to $158.00 \mathrm{mg} \mathrm{L}^{-1}$ in the euphotic layer and between $47.60 \mathrm{mg} \mathrm{L}^{-1}$ and $188.00 \mathrm{mg} \mathrm{L}^{-1}$ in the aphotic layer, as also shown in Tables II and III. These relatively high concentrations of suspended material may be related to the process of resuspension during sampling operations.

The POM distribution is also quite skewed in both layers, with lower medians in the euphotic layer. The upper limit for this layer corresponds to $94 \mathrm{mg} \mathrm{L}^{-1}$, determined at Station 100, close to the mouth of the Amazon River. Even though the maximum single POM concentration has been detected in the euphotic layer, the POM levels in the aphotic layer were generally higher, as indicated by the positions of the respective boxes and the $46.80 \mathrm{mg} \mathrm{L}^{-1}$ median value (Table III and Fig. 5).

The PIM distributions follow the same pattern, with the difference that the median values are quite close for the two layers (euphotic: $23.10 \mathrm{mg} \mathrm{L}^{-1}$; aphotic: 26.60 ). This may be explained by the balance between the resuspension and deposition processes.

Anomalous DIN amounts were calculated as described in DeMaster et al. (1996), using solely the

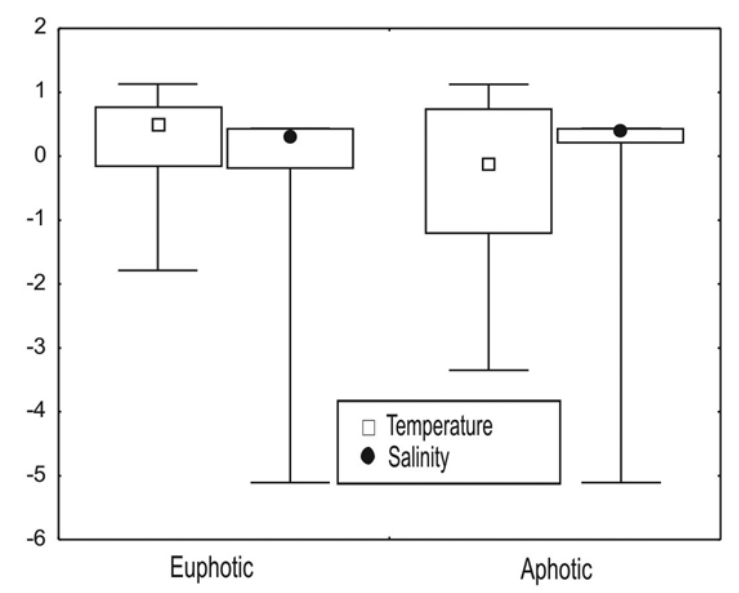

Fig. 3 - Autoscaled value distributions for temperature and salinity.

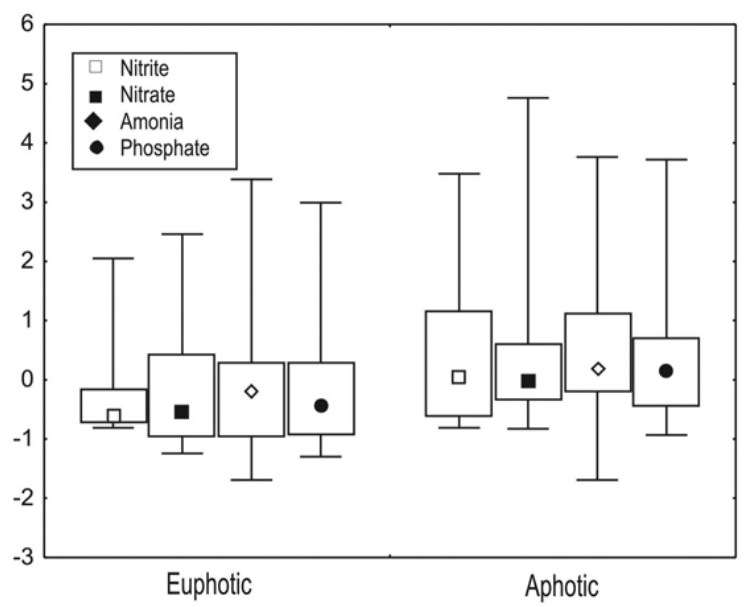

Fig. 4 - Autoscaled value distributions for nitrite, nitrate, ammonia and phosphate.

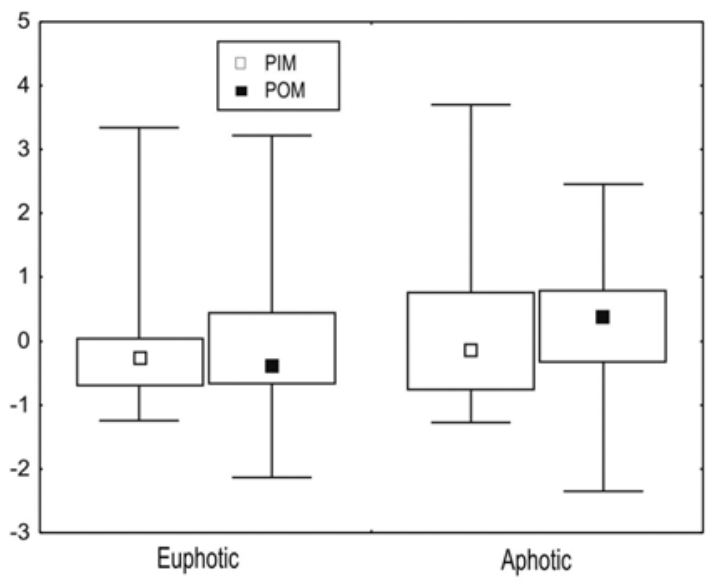

Fig. 5 - Autoscaled value distributions values for suspended particulate inorganic (PIM) and organic (POM) materials. 
superficial data. The distribution of DIN anomalies (Fig. 6) shows positive rises between the mouth of the Amazon River and Cape Orange, suggesting that in this area the addition of this nutrient occurs not only through fluvial input, but also through other processes such as, for example, nitrification and the oxidative decomposition of organic material. On the other hand, negative amounts predominated in a large area of the Amazon Continental Shelf, indicating larger removal than addition of dissolved inorganic nitrogen.

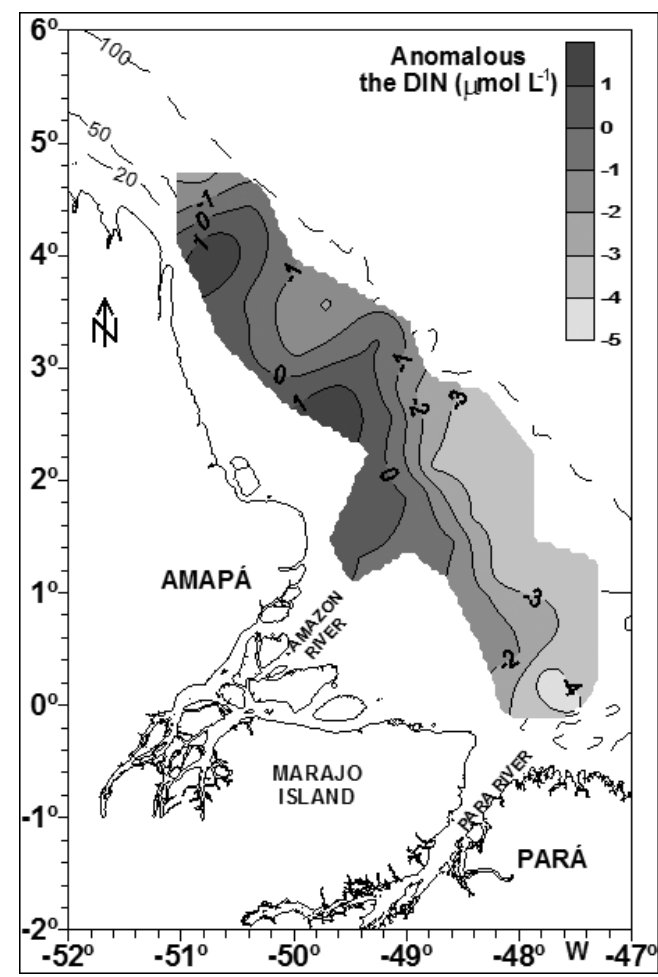

Fig. 6 - Superficial distribution of the anomalous dissolved inorganic nitrogen data (DIN) during the Amazon's falling discharge period at the Amazon Continental Shelf.

Spatial Distribution of Phosphate And Nitrate IN THE AMAZON SHELF

The bidimensional model used to represent the phosphate and nitrate spatial distributions in the superficial layer of the Amazon Continental Shelf, though simplified, contemplates the main mechanisms of influence on the balance of mass of these nutrients in the study area (Figs. 7-10). From a hydrodynamical point of view, the model is based on the assumption of the preponderance of advective and diffusive processes along the axis situated parallel to the North Brazilian coast, resulting mainly from the action of the North Brazilian Current. With respect to the biogeochemical processes, the model assumes a flux of mass resulting from the balance between production mechanisms and the constituent consumption.

Figures 7 and 8 present the distributions of the superficial phosphate and nitrate concentrations in the Amazon Continental Shelf, obtained during the North IV Operation (2001), in the falling discharge period of the Amazon River. In these figures, these distributions are compared with the results of the simulations with the MAAC-2D model. In general, the figures indicate a certain similarity, with the largest concentrations occurring close to the coast, a reduction towards the open sea and a northwesterly water mass transport caused by the North Brazilian Current.

The superficial phosphate and nitrate data obtained during the North III Operation (1999), carried out in the high discharge period, are presented in Figures 9 and 10, respectively. As in the previous figures, field data are comparable to those derived from the MAAC-2D model simulations.

\section{DISCUSSION}

The temperature dispersion in the euphotic layer is slightly skewed, with a median close to the higher values and a longer lower tail. In the aphotic layer, the skewness is less pronounced, with smaller median and minimum values, indicating a temperature drop with increasing depth, as one would expect (Fig. 3). The median temperature in this layer was $27.51^{\circ} \mathrm{C}$, while in the euphotic layer it was $28.08^{\circ} \mathrm{C}$ (Tables II and III). The distribution of this parameter confirms studies developed for the Northern ZEE (Ryther et al. 1967, M.L.S. Santos, unpublished data, Eschrique et al. 2006), which describe a thermal stability in the superficial layer, a temperature drop with increasing depth and the presence of the thermocline in the oceanic area.

The presence of waters discharged by the Amazon River is confirmed by the minimum salinity rate value of 0.00 observed in both layers and by the extreme skewness of the salinity value distributions, which have very long lower tails (Fig. 3). However, oceanic waters predominate in both layers (36.01 and 36.18 median values 

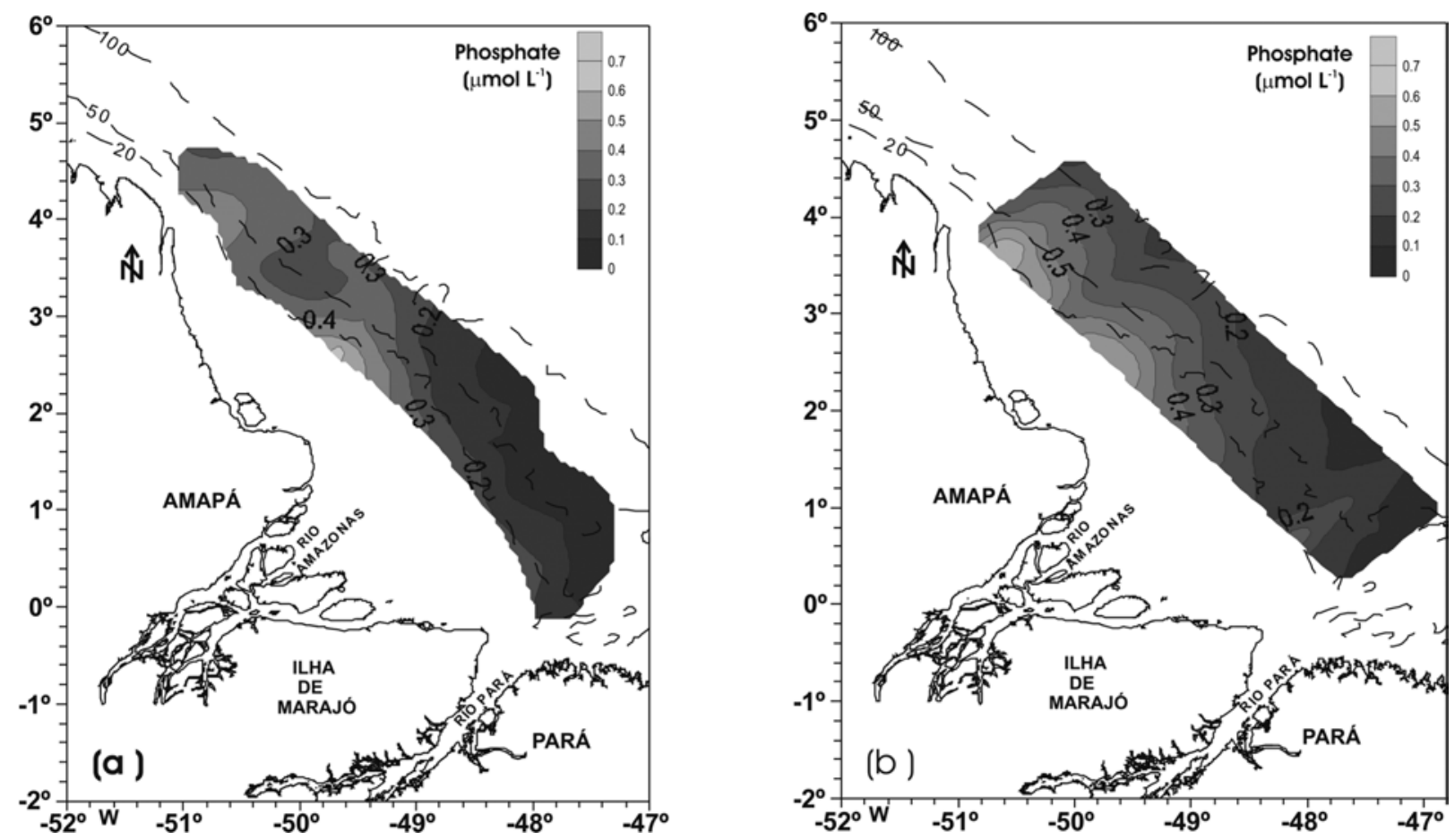

Fig. 7 - Distribution of the superficial concentration of the phosphate during Operation Norte IV (falling discharge of the Amazon River): (a) REVIZEE data; and (b) MACC-2D model results.
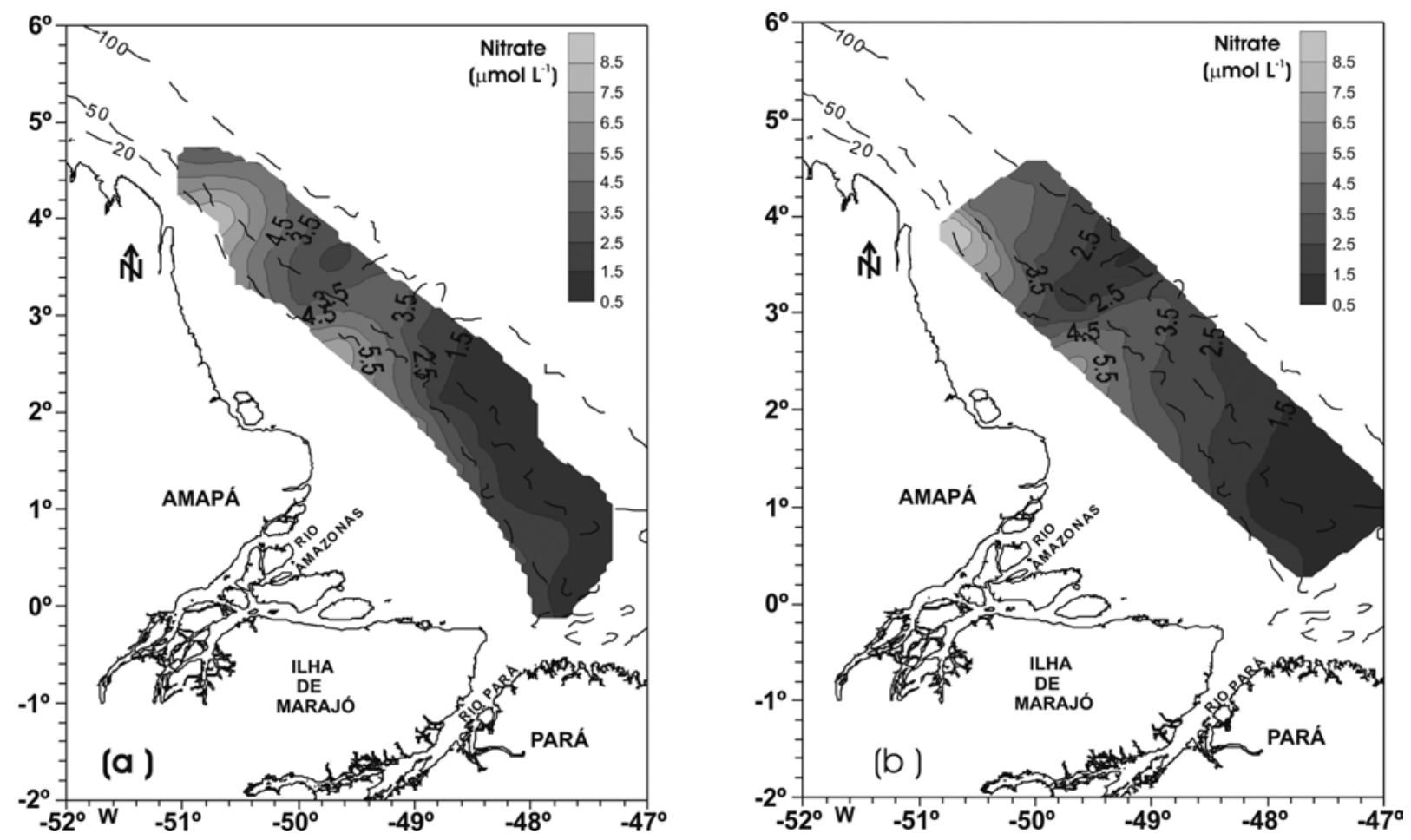

Fig. 8 - Distribution of the superficial concentration of the nitrate during Operation Norte IV (falling discharge of the Amazon river): (a) REVIZEE data; and (b) MACC-2D model results. 

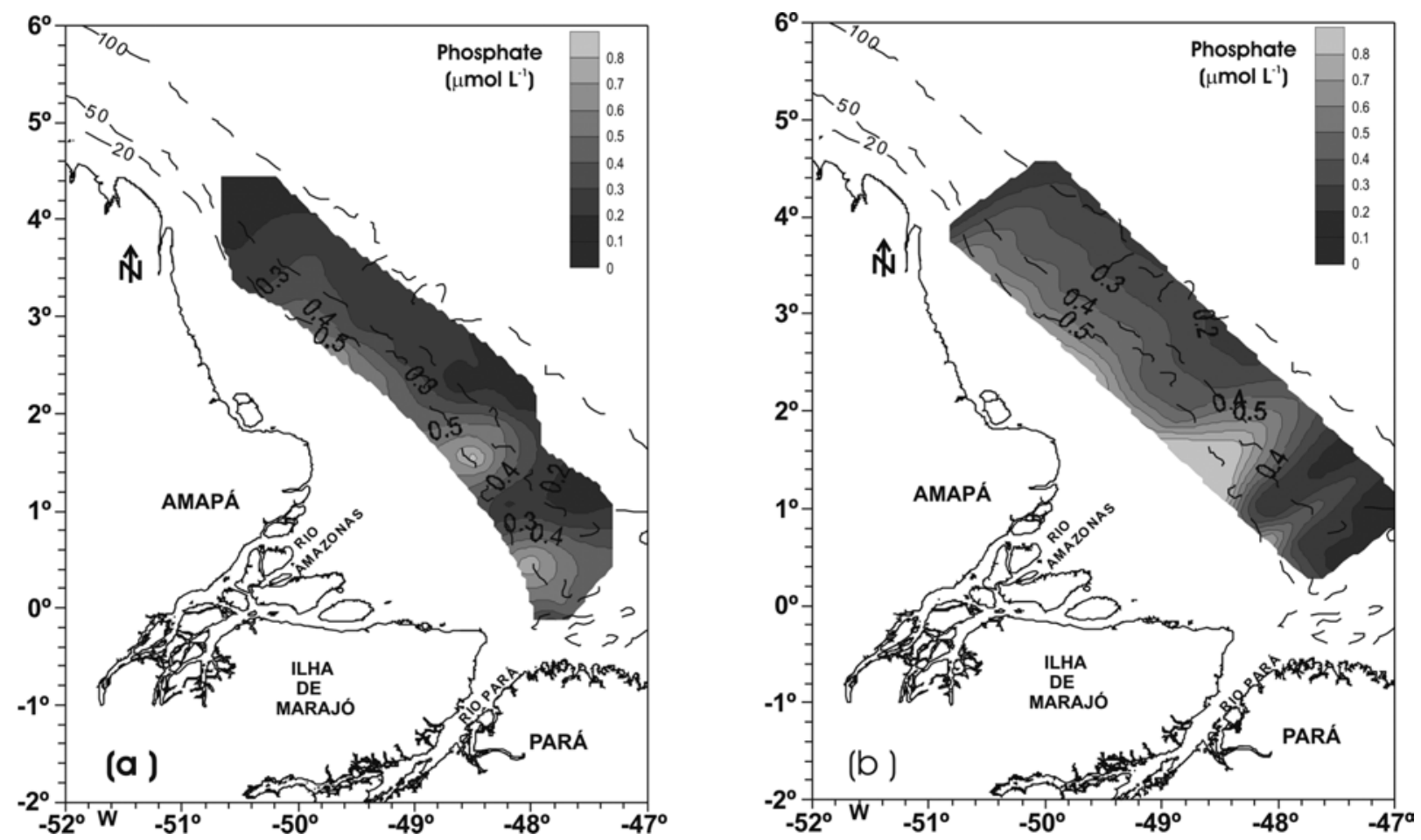

Fig. 9 - Distribution of the superficial concentration of the phosphate during Operation Norte III (high discharge of the Amazon river): (a) REVIZEE data; and (b) MACC-2D model results.
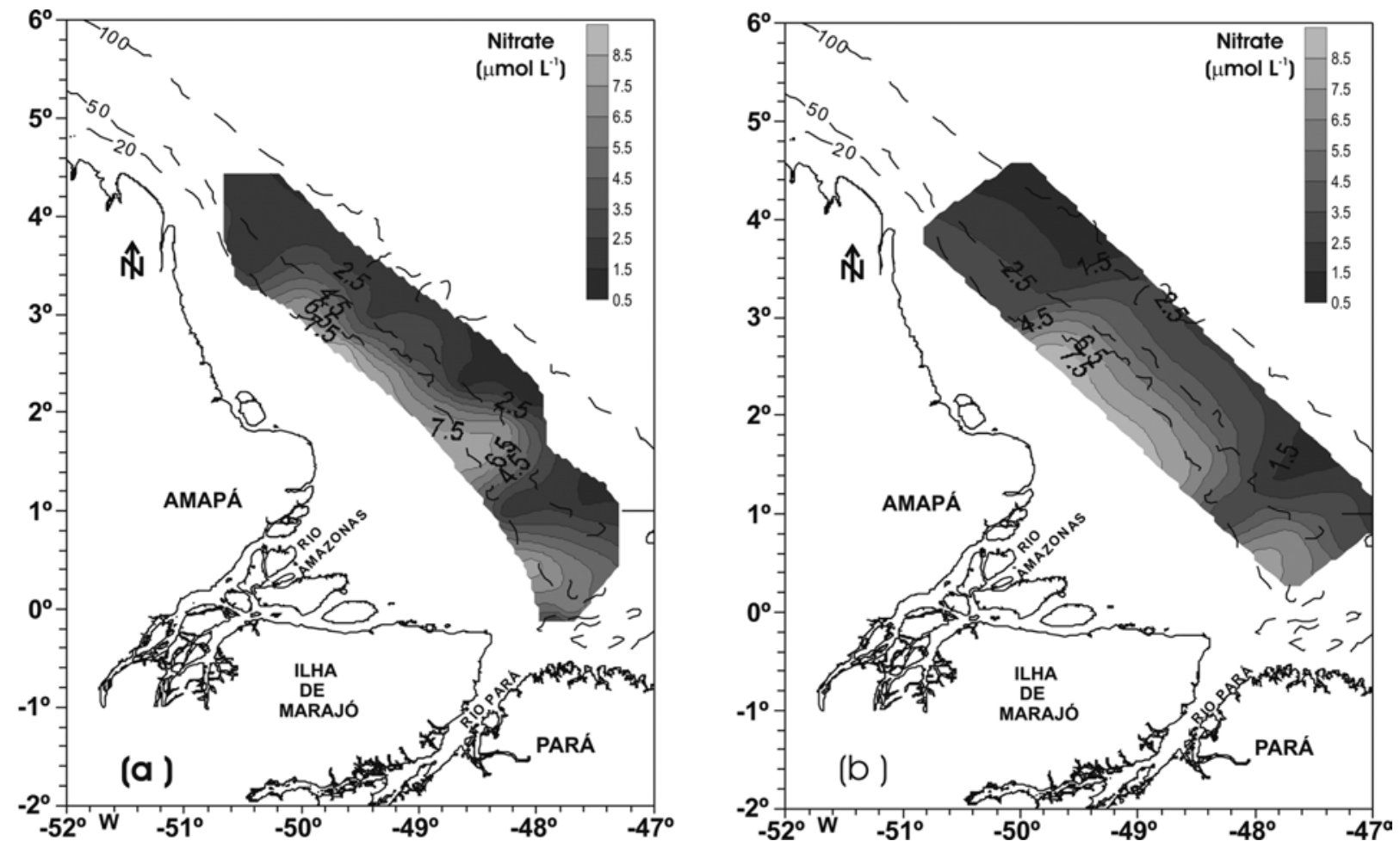

Fig. 10 - Distribution of the superficial concentration of the nitrate during Operation Norte III (high discharge of the Amazon river): (a) REVIZEE data; and (b) MACC-2D model results. 
in the euphotic and aphotic layers, respectively), with the medians very close to the maximum values (Tables II and III). The interquartilic distance in the aphotic layer is significantly lower, indicating a narrower distribution for the salinity rates, as shown in Figure 3.

The low salinity values caused by the Amazon River discharge are observed in a northwesterly direction, due to the transport performed by the North Brazilian Current. Lentz (1995a) observed that from August to October approximately $70 \%$ of the Amazon plume is transported westwards, during the retroflection of the North Brazilian Current, while the remaining 30\% are advected in a northeast direction towards the Caribbean. The mixed zone between the river and the ocean occurs at the shelf, because of the Amazon River immense discharge (DeMaster et al. 1996).

According to Carvalho and Cunha (1998), the Andean Mountain Chain (source of the Solimões and Madeira Rivers) constitutes the main natural source of sediments for the Amazon River. The suspended material in the Amazon Basin is not uniformly distributed. In 1983, during the high discharge period, Curtin and Legeckis (1986) found concentrations of approximately $200 \mathrm{mg} \mathrm{L}^{-1}$ near the river mouth. Moreover, high suspended sediment concentrations (> $544 \mathrm{mg} \mathrm{L}^{-1}$ ) were observed by these authors in the Northwestern coast (approximately as far as the $10 \mathrm{~m}$ isobar), and significant concentrations $\left(>10 \mathrm{mg} \mathrm{L}^{-1}\right)$ in the superficial waters up to approximately $200 \mathrm{~km}$ towards the open sea.

Milliman et al. (1974), in a study performed between February and March 1973 (period of rising discharge), related values of suspended organic material larger than $4 \mathrm{mg} \mathrm{L}^{-1}$ close to the outflow of the Amazon estuary and lower than $0.20 \mathrm{mg} \mathrm{L}^{-1}$ in the oceanic waters. These authors described the suspended inorganic material as consisting of sandy grains and non-combustible biogenic material, in approximately equal proportions.

In the present study, POM quantities were larger than those described by Milliman et al. (1974). However, several physical processes, in addition to the seasonality of the river discharge, characterize the hydrodynamics of the Amazon Continental Shelf.

Nitrate was the dominant form of dissolved inorganic nitrogen found in this study. The values reported here are similar to those described by Santos (M.L.S.
Santos, unpublished data) during the high discharge period of the Amazon River (euphotic layer: $1.02 \mu \mathrm{mol} \mathrm{L}^{-1}$

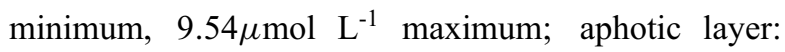
$2.19 \mu \mathrm{mol} \mathrm{L}^{-1}$ minimum, $10.21 \mu \mathrm{mol} \mathrm{L}^{-1}$ maximum).

In impacted areas, such as, for example, the Chinese estuaries, nitrate concentrations are high (Yalujiang, 309.8 $\mu \mathrm{mol} \mathrm{L}^{-1}$, Huanghe $121.0 \mu \mathrm{mol} \mathrm{L}^{-1}$, Changijiang, $32.9 \mu \mathrm{mol} \mathrm{L}^{-1}$ Minjiang $55.5 \mu \mathrm{mol} \mathrm{L}^{-1}$, Zhang 1996). The same can be observed in the Paraíba River, South Brazil $\left(21 \mu \mathrm{mol} \mathrm{L}^{-1}\right.$ minimum and $57 \mu \mathrm{mol} \mathrm{L}^{-1}$ maximum, Silva et al. 2001). Branco apud Menezes (1999) describes waters with high ammoniacal nitrogen concentrations as being associated to recent pollution. On the other hand, with high nitrate levels indicate longtime pollution. For the Chinese estuaries, the ammonium concentration in the Changijiang was determined as $14.6 \mu \mathrm{mol} \mathrm{L}^{-1}$ (Zhang 1996). In the Paraíba River, ammonium concentration varied between $1.4 \mu \mathrm{mol} \mathrm{L}^{-1}$ and $6.7 \mu \mathrm{mol} \mathrm{L}^{-1}$ (Silva et al. 2001). From the nitrate and ammonium data shown in Tables II and III, one can conclude that the area under study has not been impacted.

Santos (M.L.S. Santos, unpublished data) found higher ammonium amounts during the Amazon's high discharge period (euphotic layer: $0.01 \mu \mathrm{mol} \mathrm{L}^{-1} \mathrm{~min}$ imum and $0.91 \mu \mathrm{mol} \mathrm{L}^{-1}$ maximum; aphotic layer: $0.11 \mu \mathrm{mol} \mathrm{L}-1$ minimum and $0.97 \mu \mathrm{mol} \mathrm{L}^{-1}$ maximum) than those verified in the falling discharge period. The low ammonium concentration is the result of the heavy consumption of this nitrogenated form, which is easily assimilated by phytoplankton, and of nitrification.

The development of the marine phytoplankton is associated to the recycling of the ammoniacal nitrogen, by excretion and by degradation of dead organic material. According to Braga (E.S. Braga, unpublished data), the preference that the great majority of the marine phytoplankton has for assimilating this nitrogenated species, is largely due to the energetic gain involved in its metabolism. In oligotrophic waters, ammoniacal nitrogen assimilation can supply $80 \%$ of the local population's nitrogen requirements.

Nitrite represents an intermediary phase between the most reduced (ammonium) and the most oxidized (nitrate) nitrogen species. The values shown in Tables II and III are higher than those described by Santos 
(M.L.S. Santos, unpublished data), who found a minimum of $0.01 \mu \mathrm{mol} \mathrm{L}^{-1}$ and a maximum of $0.11 \mu \mathrm{mol} \mathrm{L}^{-1}$ in the euphotic layer, and a minimum of $0.01 \mu \mathrm{mol} \mathrm{L}^{-1}$ and a maximum of $0.09 \mu \mathrm{mol} \mathrm{L}^{-1}$ in the aphotic layer.

Total dissolved nitrogen (TDN) becomes lower with increasing depth (Tables II and III). The TDN distributions are similar to the DON distributions. On the other hand, total particulate nitrogen amounts (TPN) increase as depth increases. This suggests that the resuspension of the particulate material, phytoplankton growth and sedimentation may have contributed to the higher TPN values observed at deeper sampling stations.

DeMaster et al. (1996) described the difference between the actual dissolved inorganic nitrogen concentration (DIN) and the theoretical concentration of the mixture diagram as an anomaly of the Amazon Continental Shelf. Positive values would indicate the addition of inorganic nitrogen and negative values, the removal of this nutrient. The data of these authors reflected more assimilation than regeneration, with a negative anomaly for this nutrient.

The distribution of DIN anomalies (Fig. 6) shows positive peaks between the mouth of the Amazon River and Cape Orange, whereas negative amounts predominate in a large area of the Amazon Continental Shelf.

The data for chlorophyll $a$ is consistent with a eutrophic area (1.67 $\mathrm{mg} \mathrm{m}^{-3}$ median), indicating that there is sufficient nitrogen in the area to withstand the productivity, although with DIN removal processes that are faster than regeneration or mineralization. One can observe that nitrogen is mainly available in the two first sections of the cycle phase, in the TPN and DON forms.

The simulations with the MAAC-2D model pointed out differences in the distribution of the superficial concentrations phosphate and nitrate, according to the seasonality of the discharge of the Amazon river. High concentrations throughout the Amazon Continental shelf observed from sea data were well reproduced by the model.

During periods of transition between high and low discharges (Operation Norte IV - Figs. 7 and 8) the advection of waters from the south is enhanced as a result of the westward South Equatorial Current (SEC) and North Brazil Undercurrent (NBUC) increase over the boreal summer (Schott et al. 1998, Johns et al. 1998).
NBC currents are also accelerated by the stronger trade winds (da Silva et al. 1994), and reach their maximum at late summer, connecting with eastward NECC through the Guyana retroflection zone (Schott et al. 1998, Johns et al. 1998, Bourlès et al. 1999). So, during this period the cores of high nutrient concentrations are present in the northern part of the integration domain since at this time the transport by the NBC is greater and surface nutrient rich (and low salinity) waters would be displaced and spread northwestward (Müller-Karger et al. 1988, Johns et al. 1990, Geyer at al. 1996, Hu et al. 2004). In particular model results confirm the presence of two main cores of phosphate (Fig. 7) and nitrate (Fig. 8) placed around the coordinates $\left(2.5^{\circ} \mathrm{N}-50^{\circ} \mathrm{W}\right)$ and $\left(4^{\circ} \mathrm{N}-51^{\circ} \mathrm{W}\right)$.

During the high discharge period (Operation Norte III - Figs. 9 and 10), the most important values of phosphate and nitrate concentrations are observed (and reproduced by the model) on the central and southern parts of the Amazonian shelf, as a result of the spreading of Amazon freshwater outflow. High concentrations are also verified along the Pará coast and are mainly induced by increasing trade winds shear, which transport freshwater lenses southwestward during this boreal spring season (e.g. Geyer et al. 1996, Silva et al. 2007). Model results confirm that high nutrient concentrations during this period are verified around $\left(0.5^{\circ} \mathrm{N}-48.5^{\circ} \mathrm{W}\right)$, as well as in the coastal water area distributed along the Amazonian shoreline between $20 \mathrm{~m}-50 \mathrm{~m}$ depth in the range $\left(1^{\circ} \mathrm{N}-3.5^{\circ} \mathrm{N}\right)$.

\section{CONCLUSIONS}

The presence on the Continental Shelf of waters from the Amazon River is indicated by low salinity levels, together with high levels of nutrients and total particulate material. On the other hand, the presence of the oceanic waters is significant during the falling of discharge period.

During this period no large variations were observed in $\mathrm{pH}$ levels, the belt was always alkaline, and the dissolved oxygen values characterize the area as a saturated to supersaturated environment. Of the nitrogen cycle phases, dissolved organic nitrogen predominates, followed by total particulate nitrogen, nitrate, ammonium and nitrite, in that order, both for the euphotic 
and for the aphotic layers. The figures for nitrate and ammonium indicate a non-impacted area, and the anomalous negative values of the inorganic dissolved nitrogen in a large area of the Amazon Continental Shelf show that there is more removal than addition of this nitrogenated form.

The data for chlorophyll $a$ in the eutrophic area indicate that there is sufficient nitrogen to withstand productivity in this area, though with DIN removal processes are faster than those of regeneration or mineralization.

Simulation results obtained with the bidimensional analytical approach MAAC-2D model confirmed that the main geophysical processes contributing to the horizontal distribution of nutrients in the Amazonian shelf is the temporal changes in continental rivers discharges associated to seasonal variability of NBC and trade winds. During periods of transition between high and low discharges high phosphate and nitrate concentrations are present in the northern part of coastal area once nutrients are transported northwestward by a strongest NBC, while during the high discharge period phosphate and nitrate concentrates on the central and southern parts of the Amazonian shelf, as a result of the spreading of Amazon freshwater outflow.

\section{ACKNOWLEDGMENTS}

We thank the scientific and crew-members of the $R / V$ Antares of the Brazilian Navy for their effort and dedication during the oceanographic expeditions, as well as the Conselho Nacional de Desenvolvimento Científico e Tecnológico (CNPq) and the Brazilian Navy for support. The authors also thank the anonymous referees for their fruitful comments on this paper.

\section{RESUMO}

O estuário do rio Amazonas é notável na Plataforma Continental do Amazonas, onde a presença das águas fluviais foi detectada, mesmo durante o período da diminuição da descarga desse rio, pelos baixos valores de salinidade e altos valores de nutrientes. Contudo, a presença das águas oceânicas também foi marcante. Em relação às fases do ciclo do nitrogênio, o nitrogênio orgânico dissolvido foi a forma predominante, seguido do nitrogênio total particulado, nitrato, amônia e nitrito. Os dados de clorofila $a$ indicaram uma área eutrófica onde há nitrogênio embora os valores da anomalia do nitrogê- nio inorgânico dissolvido tenham mostrado que ocorre maior remoção do que adição dessa forma nitrogenada na área em estudo. Os resultados das simulações com o modelo bidimensional MAAC-2D confirmaram que as águas ricas em nutrientes são deslocadas para noroeste (dois núcleos em $2,5^{\circ} \mathrm{N}-50^{\circ} \mathrm{W}$ e $4^{\circ} \mathrm{N}-51^{\circ} \mathrm{W}$ ), pela ação de uma $\mathrm{CNB}$ mais forte durante o período de decaimento da vazão dos rios. No período de vazão máxima, estas lentes de águas ricas de nutrientes distribuem-se próximo de $0,5^{\circ} \mathrm{N}-48,5^{\circ} \mathrm{W}$, bem como ao longo da plataforma Amazônica rasa $\left(20 \mathrm{~m}-50 \mathrm{~m}\right.$ profundidade, $\left.1^{\circ} \mathrm{N}-3,5^{\circ} \mathrm{N}\right)$, como resultado do espalhamento da água doce de origem continental.

Palavras-chave: Plataforma Continental do Amazonas, nitrogênio, fosfato, modelagem matemática.

\section{REFERENCES}

Beardsley RC, Candela J, Limeburner WR, Geyer SJ, LEnTz BM, CASTRo D, CACCHIONE AND CARNEIRO N. 1995. The M2 tide on the Amazon shelf. J Geophys Res 100: 2283-2319.

Bourlès B, Gouriou Y AND ChuChla R. 1999. On the circulation in the upper layer of the western equatorial Atlantic. J Geophys Res 104: 21151-21170.

Carvalho NO And Cunha SB. 1998. Estimativa da carga sólida do rio Amazonas e seus principais tributários para a foz e oceano: uma retrospectiva. Revista técnica e informativa da CPRM 4: 44-58.

CLIPPER PROJET TEAM 2000. 1/6 Atlantic Circulation model forced by the ECMWF clymatology: preliminary results. LEGI report number CLIPPER-R2, also available at www.ifremer.fr/lpo/clipper.

CURTIN TB AND LEgeckis RV. 1986. Physical observation in the plume region of the Amazon River during peak discharge - I. Surface variability. Cont Shelf Res 6: 31-51.

DA Silva A, Young AC AND Levitus S. 1994. Atlas of surface marine data 1994, Vol. I: Algorithms and procedures. NOAA Atlas NESDIS 6, U.S. Department of Commerce, Washington, D.C.

DeMaster DJ AND Pope RH. 1996. Nutrient dynamics in Amazon shelf waters: results from AMASSEDS. Cont Shelf Res 16: 263-289.

DeMaster DJ, Smith WO, Nelson DM and Aller JY. 1996. Biogeochemical processes in Amazon shelf waters: chemical distributions and uptake rate of silicon, carbon and nitrogen. Cont Shelf Res 16: 617-643.

Eschrique SA, Santos MLS, Saraiva ALL, Delfino IB AND Botelho VF. 2006. Estudo dos nutrientes no ambiente pelagico adjacente à costa do Estado do Pará. Arq Ciências do Mar 39: 120-130. 
Geyer WR, Beardley RC, Lentz SJ, Candela J, Limeburner R, Johns EW, CASTRo MB AND SOARES DI. 1996. Physical oceanography of the Amazon shelf. Cont Shelf Res 16: 575-616.

Grasshoff K, Ehrhardt M And Kremling K. 1983. Methods of seawater analysis, $2^{\text {nd }}$ ed., Verlage Chemie.

Hu C, Montgomery ET, Schmitt RW and MüllerKARGER FE. 2004. The Amazon and Orinoco river plumes in the tropical Atlantic and Caribbean sea: observation from space and S-PALACE floats. Deep-Sea Res II 51: 1151-1171.

Humborg C. 1997. Primary productivity regime and nutrient removal in the Danube estuary. Estuar Coast Shelf Sci 45: 579-589.

Johns WE, LeE TN, SchotT FA, ZANTopp RJ AND EvAns RH. 1990. The North Brazil Current retroflection: seasonal structure and eddy variability. J Geophys Res 95: 22103-22120.

Johns WE, BeArdsley RC, CANDEla J, Limeburner R AND CASTRO B. 1998. Annual cycle and variability of the North Brazil Current. J Phys Ocean 28: 103-128.

JøRGENSEN SE AND BENDORICCHIO G. 2001. Fundamentals of ecological modelling. Developments in Environmental Modelling 21. Elsevier Sciences Publishers, 530 p.

Kineke CG, Sternberg WR, Trowbridge HE And GEYER RW. 1996. Fluid-mud processes on the Amazon Continental Shelf. Cont Shelf Res 16: 667-696.

LENTZ SJ. 1995a. Seasonal variations in the horizontal structure of the Amazon plume inferred from historical hydrographic data. J Geophys Res 100: 2391-2400.

Lentz SJ. 1995b. The Amazon River plume during AmasSeds: subtidal current variability and the importance of wind forcing. J Geophys Res 100: 2377-2390.

Menezes LBC. 1999. Caracterização biogeoquímica de ecossistemas Amazônicos: rios e lagos selecionados nas microregiões Bragantina, do Salgado e Guajarina, PA. Tese de Doutorado, Universidade Federal do Pará.

Milliman JD, Summerhayes CP ANd Barretto HT. 1974. Contribuição ao estudo de material em suspensão na plataforma continental do Amazonas. Congresso Brasileiro de Geologia. 3: 263-282.

Müller-Karger FE, McClain CR And Richardson P. 1988. The dispersal of Amazon's water. Nature 333: 56-59.

Nittrouer CA And DeMaster DJ. 1996. The Amazon shelf setting: tropical, energetic and influenced by a large river. Cont Shelf Res 16: 553-573.
Nittrouer CA, DeMaster DJ, Figueiredo AG AND RINE JM. 1991. AMASSEDS: an interdisciplinary investigation of a complex coastal environment. Oceanography 4: $3-7$.

Paranhos R. 1996. Alguns métodos para análise da água. UFRJ.

Philander SGH AND PACANOWSKI. 1986. The mass and heat nudget in a model of the tropical Atlantic Ocean. J Geophys Res 92: 3691-3708.

Picaut J, Servain J, Lecompte P, Seva S, Lukas S AND Rougier G. 1985. Climatic atlas of the tropical Atlantic, wind stress and sea surface temperature, 19641979, Université de Bretagne Occidentale, 467 p.

Ryther JH, Menzel DW And Nathaniel C. 1967. Influence of the Amazon river outflow on the ecology of the western tropical Atlantic I. Hydrography and nutrient chemistry. J Mar Res 25: 69-83.

Schott FA, Fischer J And Stramma L. 1998. Transports and pathsways of the upper-layer circulation in the western tropical Atlantic. J Phys Oceanogr 28: 19041928.

Schott FA, Dengler M, Brandt P, AfFler K, FisCHER J, Bourles B, GOURIOU Y, MOLINARI RL AND RHEIN M. 2003. The zonal currents and transports at $35^{\circ} \mathrm{W}$ in the tropical Atlantic. Geophys Res Lett 30(7), 1349, doi:10.1029/2002GLO16849.

SILVA AC. 2006. An analysis of water properties in the western tropical Atlantic using observed data and numerical model results. Tese de Doutorado, Universidade Federal de Pernambuco, $155 \mathrm{p}$.

Silva AC, Bourlès B And Araujo M. 2007. Seasonal variability of the Amazon river plume during REVIZEE Program. Tropical Ocean 35(2): 92-109.

Silva MAL, CALAsAns CF, Ovalle ARC AND REZENDE CE. 2001. Dissolved nitrogen and phosphorus dynamics in the lower portion of the Paraíba do Sul River, Campos dos Goytacazes, RJ, Brazil. Braz Arch Biol Technol 44: 365-371.

STRICKLAND JDH AND PARSONS TR. 1972. A practical handbook of sea water analysis. Bull Fish Res Board Can 167: 1-311.

TEIXEIRA C. 1973. Introdução aos métodos para medir a produção primária do fitoplâncton marinho. Bol Inst Oceanogr 22: 59-92.

UNESCO. 1973. International oceanographic table.

ZHANG J. 1996. Nutrient elements in large Chinese estuaries. Cont Shelf Res 16: 1023-1045. 